\title{
The wealth effects of REIT property acquisitions and dispositions: the creditors' perspective
}

Article

Accepted Version

Li, Q., Ling, D. C., Mori, M. and Ong, S. E. (2020) The wealth effects of REIT property acquisitions and dispositions: the creditors' perspective. The Journal of Real Estate Finance and Economics, 60. pp. 308-337. ISSN 0895-5638 doi: https://doi.org/10.1007/s11146-018-9677-9 Available at https://centaur.reading.ac.uk/79270/

It is advisable to refer to the publisher's version if you intend to cite from the work. See Guidance on citing.

To link to this article DOI: http://dx.doi.org/10.1007/s11146-018-9677-9

Publisher: Springer

All outputs in CentAUR are protected by Intellectual Property Rights law, including copyright law. Copyright and IPR is retained by the creators or other copyright holders. Terms and conditions for use of this material are defined in the End User Agreement.

www.reading.ac.uk/centaur 
Central Archive at the University of Reading

Reading's research outputs online 


\title{
The Wealth Effects of REIT Property Acquisitions and Dispositions: The Creditors' Perspective
}

\begin{abstract}
Prior studies of REIT property transaction activity focus on shareholder wealth effects. This study examines the effects of property acquisitions, dispositions, and overall trading activity on unsecured bond spreads, credit rating changes, and rating outlooks using a sample of the listed equity REITs in the U.S. We find that active property trading in general decreases creditors' wealth, but this negative impact is significantly mitigated for REITs with positive NAV premiums and when REITs use sale proceeds to pay down debt after the transactions. We also find that property transactions followed by an increased geographic focus significantly increase bond yield spreads and decrease the probability of credit rating upgrades.
\end{abstract}

Keywords REIT $\cdot$ Property transaction $\cdot$ Bond yield spread $\cdot$ Credit rating change JEL Codes G23 · G24 · G32 


\section{Introduction}

Property acquisitions and dispositions are a frequent and important corporate activity undertaken by Real Estate Investment Trusts (REITs). As a result, a substantial body of literature studies the effects of property acquisitions and dispositions on REITs. Most of the studies that investigate property transaction activity focus on the effects of property transaction from shareholders' perspective (e.g., Glascock et al. 1991; Mclntosh et al. 1995; Campbell et al. 2003, 2006; Brounen et al. 2007; Ooi et al. 2011). In contrast, the effects of property transaction on the wealth of creditors have been mostly neglected by the literature.

To address this gap in the real estate literature, we examine how equity REIT decisions on property acquisitions and dispositions affect the wealth of creditors. ${ }^{1}$ We use corporate bond yield spreads and credit rating changes as proxies for debt holders' wealth. Since bond yields and credit ratings affect the cost of debt financing, it is important for corporate managers to understand how their corporate decisions affect bond yields and credit ratings (see, e.g., Kisgen 2006).

The value of REITs is sensitive to the cost of debt financing, because regulations require REITs to rely heavily on external funds, including debt to finance their property investments (e.g., Ooi et al. 2010; Ong et al. 2011). ${ }^{2}$ The heavy reliance on external financing may create agency conflicts between debt and equity holders along with asset transactions (Jensen and Meckling 1976; Myers 1977). Due to the potential conflict of interests, the effects of property transactions on debt holders can be quite different from the effects on equity holders. In addition, REITs tend to maintain significantly higher debt ratios than their non-REIT counterparts (Feng et al. 2007; Li et al. 2014;

\footnotetext{
${ }^{1}$ Equity REITs take ownership positions in commercial real estate. In contrast, mortgage REITs own mortgages or mortgagebacked securities.

${ }^{2}$ REITs must distribute 90 percent of annual taxable income to remain a qualified REIT. REITs must distribute all of their taxable income in the form of dividends to completely avoid taxation at the entity level. These dividend payments constitute approximately 70 percent of free cash flow for the typical REIT.
} 
Giacomini et al. 2017). Thus, it is essential for REIT managers to understand the relation between property transaction decisions and their firms' credit assessments.

Our two proxies for debt holders' wealth are bond yield spreads and credit rating changes. In addition to actual credit rating changes (upgrades/downgrades), we also use an intermediate-term credit change indicator--rating outlook--as a dependent variable. ${ }^{3}$ Given that rating agencies are often accused of being slow to adjust their ratings (Löffler 2005; Cheng and Neamtiu 2009), we expect rating outlooks to capture more timely changes in the perceived credit quality of REITs after property transactions.

In addition to examining the effects of property transactions on bond yield spreads and credit rating changes, we also investigate the underlying economic channels that can explain the relation between property transaction and creditor's wealth. We focus on three hypotheses. First, the Efficient Asset Allocation Hypothesis refers to the idea that some REITs may be perceived to have better management skills and are able rebalance their REIT portfolios more efficiently. We use the firm's net asset value (NAV) premium as the Efficient Asset Allocation channel proxy to identify REITs that appear to be judged by the market as efficient asset managers. In addition, we measure the change in property portfolio quality by the change in return on average assets. The Proceeds Utilization Hypothesis suggests that REITs can use the proceeds from property dispositions to reduce leverage, which may have a positive effect on the perceived credit quality. We use the change in outstanding debt as a percentage of total assets after dispositions to test this channel. Lastly, the Focus Hypothesis suggests that the geographic and property-type concentrations of a REIT's property portfolio could be altered when property assets are sold or purchased. Conditional

\footnotetext{
${ }^{3}$ According to S\&P's, a rating outlook assesses the potential direction of a long-term credit rating over the intermediate term (typically six months to two years). In determining a rating outlook, consideration is given to any changes in economic and/or fundamental business conditions. An outlook is not necessarily a precursor of a rating change. Positive means that a rating may be raised. Negative means that a rating may be lowered.
} 
on the direction of change in focus, property transaction may have different effects on bond yield spreads and credit assessments. We calculate Herfindahl-Hirschman Index (HHI) to measure the geographic focus and property-type focus of a REIT's property portfolio. We then examine how transaction activity differentially affects bond spreads and credit rating changes, conditional on different criteria.

Our empirical results show that, in general, property transaction activity negatively affects creditors' wealth. In the first part of tests, we find a significant and positive relation between property transaction activity and REIT bond yield spreads. However, this positive relation is largely mitigated when the firm's stock is selling at a premium to its per share NAV, which is consistent with the Efficient Asset Allocation Hypothesis. We also find that an increase in geographic focus generally amplifies the effects of transaction activity on bond yield spreads. We find no support for the Proceeds Utilization hypothesis.

In the second part of our analysis, we find that increased property transaction activity tends to increase the probability of a negative credit assessment. However, we find that the negative effect of property transaction is significantly mitigated when the REIT is trading at a premium to NAV, again supporting the Efficient Asset Allocation Hypothesis. We find some support for the Proceeds Utilization hypothesis suggesting that, conditional on using proceeds to pay down debt, property transaction activity is favorably or less negatively viewed by credit rating agencies. We also find that property transaction activity that is followed by an increase in geographic focus tends to decrease the probability of an upgrade, supporting the Focus hypothesis.

This study contributes to the literature in several dimensions. First, to the best of our knowledge, we are the first to examine the wealth effect of property transaction activity from the perspective of creditors. We also propose three hypotheses to explore and explain the relation 
between property transactions and creditor's wealth. Second, the existing literature has primarily examined the short-term effect on the wealth of public bondholders after asset divestitures using cumulative bond excess returns surrounding announcements (Datta and Iskandar-Datta 1996; Datta et al. 2003). Using aggregate transaction activity as the independent variable, we are able to capture the economic effect of property transaction activity on firm credit risk, measured by both bond yield spreads and credit rating changes, over a longer time period.

Third, this study extends the work of Brounen et al. (2007) by examining the relation between active trading and debt holder's wealth. We are able to show that higher level of transaction activity tends to reduce creditors' wealth; however, certain conditions tend to mitigate the negative effect of active trading activity. Lastly, this paper contributes to the literature related to diversification effect on cost of debt. Using the REIT market as a special laboratory, we capture the effects of portfolio geographic diversification on the cost of debt, in addition to the business/industry diversification effect studied in the corporate finance literature (e.g., Franco et al. 2015). The result from our study suggests that property geographic diversification (focus) decreases (increases) the cost of debt.

The rest of this paper proceeds as follows. In Section 2, we review the relevant literature and discuss the motivation for REIT property transactions. We propose three possible mechanisms to explain how property trading affects debt holder's wealth. Section 3 explains the regression models and the selection of variables. Section 4 describes the data and provides sample statistics. Section 5 discusses the empirical results. Section 6 concludes.

\section{Literature Review}




\section{Wealth Effects of Transaction Activities}

Most of the literature on asset transactions focuses on the effects on overall firm market value or shareholders' wealth; only a few studies have examined the effects of asset transaction activity on debt holders' wealth.

For corporate asset transactions, the wealth gains of shareholders are derived from three primary sources: efficient redistribution of assets, use of proceeds, and increase in focus. Efficient asset redistribution occurs when the transaction is efficient; for example, when the buyer values the asset more than the seller does. When this occurs, some of the buyer's value gains will be captured by the seller through a premium in the selling price. Studies on corporate asset sell-offs find that the abnormal returns range from $0.5 \%$ to $1.66 \%$ and are attributed primarily to efficient reallocation of assets to higher-valued uses (Alexander et al. 1984; Hite et al. 1987; Jain 1985). On the other hand, Lang et al. (1995) propose a financing hypothesis to explain value creation from asset sales. They find significant and positive abnormal returns for the payout subsample, but no significant effect for the sample of firms that retain sales proceeds. John and Ofek (1995) find that selling assets unrelated to the firm's core business leads to an increase in focus and efficiency. Therefore, the positive announcement effect on stock returns is greater for focus-increasing divestitures.

A substantial portion of the existing REIT literature studies the wealth implication of property trading activities from the perspective of shareholders. Most of these studies focus on either acquisitions or dispositions. McIntosh et al. (1995) find that REIT sellers who declare a one-time increase in dividends funded by the dispositions experience a share price increase. Campbell et al. (2003) observe positive abnormal returns surrounding the announcement of acquisitions. They provide evidence that the excess returns result from the increase in the geographic focus from the 
acquisition. Campbell et al. (2006) find that abnormal returns from REIT sell-offs are inversely related to firms' operating performance prior to the sale. This result is consistent with the asset efficiency explanation of shareholder returns.

Brounen et al. (2007) study the effect of property acquisitions, dispositions, and trading intensity on REIT stock returns. They measure trading intensity by summing acquisitions and dispositions and posit that a high level of asset trading is a proxy for an active management strategy. They find that active trading does not generate outperformance.

Among the few studies that have examined the effects of asset transaction activity on debt holders' wealth, Datta and Iskandar-Datta (1996) and Datta et al. (2003) examine the wealth implications for bondholders and the net valuation effect on the firm as a whole. Using cumulative excess bond returns and cumulative stock returns after the divestiture transactions as proxy for bondholders' and shareholders' wealth, respectively, they find that divestitures are generally value enhancing to both stockholders and bondholders of the selling firm.

As summarized above, the impact of property transactions on creditor's wealth has been neglected in the previous research. This study fills the gap by investigating the trading activity of REITs from the perspective of debt holders. We examine the effects of acquisitions and dispositions, as well as the overall trading activity following Brounen et al. (2007).

\section{Reasons behind Property Transactions}

Prior studies suggest three primary reasons, or channels, to explain the relation between portfolio transaction activity and perceived credit risk. First, REITs generally attempt to improve asset quality through acquisitions and dispositions. As stated in the 2009 annual report of Apartment Investment and Management Company: 
"We intend to upgrade the quality of our portfolio through the sale of approximately $5 \%$ to $10 \%$ of our portfolio annually, with the proceeds generally used to increase our allocation of capital to well-located properties within our target markets through capital investments, redevelopment or acquisitions. We expect that increased geographic focus will also add to our investment knowledge and increase operating efficiencies based on local economies of scale."

In support of this view, Warusawitharana (2008) examines corporate asset transaction and reports evidence of relation between asset quality and transactions: more specifically, a decrease in the return on assets increases the likelihood of an asset sale.

The second reported reason for REIT property transactions is the desire to utilize the proceeds from dispositions to reduce debt and/or to fund acquisitions. Studies on non-real estate asset selloffs by conventional firms tend to find that management's decision to use sale proceeds to retire debt does not affect shareholder valuations. In fact, Lang et al. (1995) show that firms selling assets tend to be poor performers with high leverage. REIT disposition announcements often mention that one use of the proceeds will be to pay down debt and/or to make new acquisitions. For example, on October 27, 2005, the report of the Associated Estates Realty Corporation regarding the third quarter results indicated the following:

"In August, the Company completed the sale of The Triangle Apartments, a 279-unit apartment community in Cleveland, $\mathrm{OH}$, to nearby Case Western Reserve University (CWRU). The Company continues to manage the property for CWRU. The Company also completed the sale of Windsor at Metrowest, a 460-unit community in Orlando, on October 24. Proceeds from the sales of properties are currently being used to pay down debt, repurchase shares of the Company's stock, and to acquire or develop properties."

Another reason for asset turnover is to increase the focus of the REIT by property type and/or geographic location. John and Ofek (1995) emphasize focus as an important motive for divestitures of corporate assets. Lang and Stulz (1994), Comment and Jarrell (1995), and Berger and Ofek (1995) all suggest that an increase in focus results in increased equity market value. Therefore, reducing the geographic dispersion of the firm's asset base is an important motivation for a REIT 
to reallocate its portfolio. This is reflected in the American Campus Communities Incorporated Third Quarter 2006 Earnings Conference Call on November 2, 2006:

"On our last call, we announced that we were in the process of marketing The Village on University in Tempe, Arizona for sale. This strategic disposition gives us an opportunity to accretively recycle capital into the acquisition opportunities Bill previously discussed as well as to the pipeline development projects. This disposition also mitigated market exposure in Tempe as we bring newer, better-located product on line in the ASU market."

Based on the literature of asset transactions and the reasons for REITs to buy and sell properties, we suggest three possible hypotheses that explain the wealth implication of property transaction on creditors.

The Efficient Asset Allocation Hypothesis has twofold implications. First, REITs perceived to have better management skills are able to reallocate their properties more efficiently. Ling et al. (2016) observe that high asset growth REITs tend to underperform low growth REITs, a typical finding in the general finance literature. However, they find that the growth effect is less negative, or nonexistent, for REITs selling at a premium to NAV. This result implies that, for firms that can fund asset growth in an efficient way (with cost of capital advantage), the negative effect of asset growth is alleviated. Second, REITs can alter the overall quality of their property portfolios through property trading activities. We interpret transactions which increase property quality as efficient asset allocation. Focusing on equity REIT property sell-offs, Campbell et al. (2006) find that abnormal shareholder returns are inversely related to a firm's operating performance prior to the sell-off announcement. This finding is consistent with their hypothesis that the positive stock price response from asset sales results from asset reallocation efficiencies. We expect the efficient allocation of assets also adds to value to the positions of creditors.

The Proceeds Utilization Hypothesis suggests REITs may use the proceeds from property dispositions to pay down debt or finance new investments. Therefore, dispositions may have a 
positive effect on a firm's financial profile because debt repayment reduces the leverage ratio and expands the potential for future profitable investment. However, this hypothesis may not hold for several reasons. First, managers may undertake a risky investment to push up the stock price in the short run at the expense of debt holders' wealth. In the long run, this risk-shifting opportunistic behavior will eventually increase the firm's credit risk. Bond investors and credit rating agencies that measure default risk over long investment horizons may detect these value-decreasing investment decisions even when they temporarily boost stock prices. Thus, we have uncertain expectations about the impact of disposition proceeds on bond yields and credit ratings.

The last mechanism we examine is characterized by the Focus Hypothesis. There are two types of focuses for real estate assets: property type and geographic location. Firms can increase the level of business focus by selling non-core properties and purchasing core properties. The geographic focus of a firm may also be changed through property transactions. Mansi and Reeb (2002) argue that diversification enhances bondholder value due to a reduction in firm risk. They suggest that shareholder equity is a call option on the value of the firm exercised in states where the value of the assets is greater than the value of the debt claim. Increasing the riskiness of the firm increases the value of the shareholders' call option but decreases bondholder value.

Using a sample of commercial bank loans, Demirci et al. (2018) do find that loan spreads tend to decline when REITs diversify across property types. They argue that equity holders are exposed to both the upside and downside of cash flow volatility, while bond holders are mostly concerned with downside risk. The risk arising from managerial specialization will not increase loan performance, but may increase default risk and widen loan spreads. We therefore expect a negative relation between trading activity and creditor's wealth when property transactions result in higher levels of concentration. 


\section{Methodology}

\section{Testing the Effects of Transaction Activity on Bond Yield Spreads}

To test the effects of transaction activity on bond yield spreads, we first regress observed spreads on several transaction proxies and a set of control variables:

$$
\begin{aligned}
& \text { Spread }_{i, t}=\beta_{0}+\beta_{1} \text { Transaction Proxy }_{i, t-1}+\beta_{2} \text { Firm Size }_{i, t-1}+ \\
& \beta_{3} \text { Leverage }_{i, t-1}+\beta_{4} \text { Age }_{i, t}+\beta_{5} \text { Intcov }_{i, t-1}+\beta_{6} \text { FFO }_{i, t-1}+\beta_{7} \text { DPS }_{i, t-1}+ \\
& \beta_{8} \text { CLD }_{i, t-1}+\beta_{9} \text { Rating }_{i, t-1}+\beta_{10} \text { Coupon }_{i}+\beta_{11} \text { Issue Size }_{i}+\beta_{12} \text { Maturity }_{i, t}+ \\
& \beta_{13} \text { Termstr }_{t}+\beta_{14} \text { Treasury }_{t}+\varepsilon_{t}
\end{aligned}
$$

Spread $_{i t}$ is the average daily difference between the (trade-size weighted) bond yield to maturity for the firm in year $t$ and the yield on the benchmark U.S. Treasury with closest maturity in the same year. ${ }^{4}$ We use three transaction activity proxies: Acq, Disp, and Trading. Acq $q_{i, t-1}$ is equal to the aggregate contractual gross sales price of properties bought during year $t-1$, divided by average value of total assets during year $t-1$, or

$$
\operatorname{Acq}_{i, t-1}=\frac{\text { Buy }_{i, t-1}}{\left(\text { Assest }_{i, t-2}+\text { Assest }_{i, t-1}\right) / 2}
$$

$A c q_{i, t-1}$ captures acquisition activity in year $t-1$ relative to the average value of the properties in the portfolio during year $t-1$. Disp $p_{i, t-1}$ is equal to the aggregate contractual gross sales price of sold properties during year $t-1$, divided by average total asset value during the year, or

$$
\operatorname{Disp}_{i, t-1}=\frac{\text { Sell }_{i, t-1}}{\left(\text { Assest }_{i, t-2}+\text { Assest }_{i, t-1}\right) / 2}
$$

Disp $p_{i, t-1}$ captures sales activity in year $t-1$ relative to the average value of the properties in the portfolio during year $t-1 .{ }^{5}$ Finally, Trading is the sum of Acq and Disp, or

\footnotetext{
${ }^{4}$ Our weighting approach is consistent with Bessembinder et al. (2008).

${ }^{5}$ A REIT is subject under Sec. $857(\mathrm{~b})(6)(A)$ to a $100 \%$ tax on "net income derived from prohibited transactions," which generally includes net income from the sale or other disposition of property described in Sec. 1221(a)(1) - i.e., property primarily held by the REIT for sale to customers in the ordinary course of a trade of business (so-called dealer property) - and not pursuant to a foreclosure. Sec. 857(b)(6)(C) provides a safe harbor under which a prohibited transaction does not include the sale of a real estate
} 


$$
\operatorname{Trading}_{i, t-1}=\frac{\text { Buy }_{i, t-1}+\text { Sell }_{i, t-1}}{\left(\text { Assest }_{i, t-2}+\text { Assest }_{i, t-1}\right) / 2}
$$

We posit that a high level of Trading is a proxy for an active trading strategy.

Firm-level characteristics controlled for in the estimation of equation (1) include the natural logarithm of total assets (Firm Size), total debt as a percentage of total capitalization (Leverage), the number of years since the firm's IPO (Age), the interest coverage ratio (Intcov), funds from operation divided by total assets $(F F O),{ }^{6}$ dividends per share $(D P S)$, and the amount drawn on the firm's credit line(s) as a percentage of total available credit lines $(C L D)$. These firm-level controls are measured as of year ( $t$-1) except Age. According to Standard \& Poor's (2004), these firm-level controls affect the credit risk of equity REITs. High levels of Intcov and $F F O$ indicate relatively healthy firms that are likely to enjoy lower yield spreads. In contrast, high levels of Leverage and $C L D$ are expected to be predictive of higher spreads.

Following prior studies on bond yield spreads (Campbell and Taksler 2003; Chen et al. 2007), we also include a set of bond-level characteristics and macroeconomic variables as additional control variables in the estimation of equation (1). Bond characteristics include the credit rating issued by S\&P (Rating), the bond's coupon interest rate (Coupon), the natural logarithm of the bond offer amount (Issue Size), and the number of years to maturity (Maturity). Rating is a numerical value attached to each credit rating, where a higher value corresponds to lower credit quality issues. For example: $6=\mathrm{A} ; 12=\mathrm{BB}$. We use the average credit rating in year $t-1$ to predict bond yield spreads in year $t$. The coupon rate and issue size are time invariant.

Macroeconomic variables included in the analysis are the yield on the closest benchmark

asset if certain requirements are met.

${ }^{6}$ FFO, as defined under the National Association of Real Estate Investment Trusts (NAREIT) standards, consists of net earnings computed in accordance with GAAP, excluding gains (or losses) from sales of real estate assets and impairment, plus depreciation and amortization of real estate assets. 
Treasury security (Treasury) and the difference between the 10-year and 2-year Treasury yield (Termstr), which captures the slope of the term structure of interest rates. Prior studies (e.g. CollinDufresne et al. 2001) interpret Termstr as an indication of expectations of future short rates, as well as an indication of the overall health of the economy. Termstr and Treasury are calculated as daily averages over year $t$. We are primarily interested in the estimated coefficient on our transaction proxies, $\beta_{1}$.

The estimation of equation (1) allows us to examine the direct effects of transaction activity on bond yields. However, as noted earlier, the literature suggests the effects of transaction activity may be conditional on a number of factors. For example, the effect of acquisitions and dispositions may be affected by whether the REIT's stock is selling at a premium or discount to per share NAV. The effects of transaction activity on perceived credit risk may also be related to the recent operating performance of the firm, to the intended use of cash generated from dispositions, and to the extent to which acquisitions and dispositions are undertaken to alter the property type focus or geographic footprint of the firm.

To examine the extent to which the effects of transaction activity are conditional on these different channels, we next estimate the following interactive model of bond yield spreads

$$
\begin{aligned}
& \text { Spread }_{i, t}=\beta_{0}+\beta_{1} \text { Transaction Proxy }_{i, t-1}+\beta_{2} \text { Transaction Proxy }^{*} \\
& \text { Channel Dummy }_{i, t-1}+\beta_{3} \text { Channel Dummy }_{i, t-1}+\beta_{4} \text { Firm Size }_{i, t-1}+ \\
& \beta_{5} \text { Leverage }_{i, t-1}+\beta_{6} \text { Age }_{i, t}+\beta_{7} \text { Intcov }_{i, t-1}+\beta_{8} \text { FFO }_{i, t-1}+\beta_{9} \text { DPS S }_{i, t-1}+ \\
& \beta_{10} \text { CLD }_{i, t-1}+\beta_{11} \text { Rating }_{i, t-1}+\beta_{12} \text { Coupon }_{i, t}+\beta_{13} \text { Issue Size }_{i, t}+\beta_{14} \text { Maturity }_{i, t}+ \\
& \beta_{15} \text { Termstr }_{t}+\beta_{16} \text { Treasury }_{t}+\varepsilon_{t}
\end{aligned}
$$

Channel Dummy is a dichotomous variable that indicates a particular channel is in effect, such as a positive NAV premium. We discuss the selection of our channel dummy variables in detail in section 3.3. 


\section{Testing the Effects of Transaction Activity on Credit Rating Changes}

To examine how transaction activity affects credit ratings and outlook changes, we estimate the following probit regression model:

$$
\begin{aligned}
& \text { Rating Change }_{i, t}=\gamma_{0}+\gamma_{1} \text { Transaction Proxy }_{i, t-1}+\gamma_{2} C_{-} \text {leverage }_{i, t-1}+ \\
& \gamma_{3} \text { C_intcov }_{i, t-1}+\gamma_{4} C_{-} \text {FFO }_{i, t-1}+\gamma_{5} C_{-} D P S_{i, t-1}+\gamma_{6} C_{-} \text {CLD }_{i, t-1}+\gamma_{7} \text { Firm Size }_{i, t-1}+ \\
& \gamma_{8} \text { Age }_{i, t}+\gamma_{9} \text { Peer_index }_{t-1}+\gamma_{10} \text { Beta }_{i, t-1}+\gamma_{11} \text { BBBminus }_{i, t-1}+\gamma_{12} \text { BBPlus }_{i, t-1}
\end{aligned}
$$

The dependent variable, Rating Change, is one of four possible dichotomous variables, which are set to one if the bond was: upgraded sometime during year $t$ (Upgrade); downgraded during the year $t$ (Downgrade); assigned a positive credit rating outlook in year $t$ by S\&P (Positive); or assigned a negative credit rating outlook by $\mathrm{S} \& \mathrm{P}$ in year $t$ (Negative). The rating agencies are often criticized for sluggishness in adjusting their ratings. ${ }^{7}$ As discussed above, a rating outlook may provide an early indication of the potential evolution of a firm's credit rating over a period of between six months to two years. We use positive and negative rating outlooks to supplement credit rating changes to capture more timely credit risk information.

Our selection of control variables is based on a survey of credit rating research pertaining to all firm types (e.g., Amato and Furfine 2004; Altman and Rijken 2004) as well as the REIT credit rating criteria suggested by Standard \& Poor's (2004). According to Standard \& Poor's, a corporate credit rating has two major components: financial risk and business position. ${ }^{8}$ To control for changes in financial risk, we employ the annual rate of change in the five firm-level variables discussed above (DPS, FFO, Intcov, Leverage, and CLD). Firms that pay high dividends tend to have higher expectations of future cash flow and an ability to meet debt obligation. Therefore, we

\footnotetext{
${ }^{7}$ See, for example, Löffler (2005) and Cheng and Neamtiu (2009).

${ }^{8}$ According to S\&P's rating criteria for U.S. REITs and real estate operating companies (REOCs), a REIT rating analysis has two major components. The first is business position assessment, which involves the assessment and benchmarking of the company along the following key dimensions: market position, asset quality, diversification and stability of operations, and operating strategy and management review. The second is financial risk profile, which refers to four elements: financial policy, profitability, cash flow protection, and capital structure and financial flexibility.
} 
expect that dividend increases $\left(C_{-} D P S\right)$ will increase the probability of credit rating upgrades/positive outlooks. $C_{-} F F O$, defined as the year-over-year change in funds from operations (FFO) divided by total assets captures variation in a REIT's free cash flow. An increase in a firm's interest coverage ratio ( $C$ _ intcov) may also be predictive of a rating upgrade or positive outlook. C_Leverage is a direct measure of the year-over-year change in the use of debt in the firm's capital structure. An increase in leverage should be associated with increased credit risk, on average. Finally, as a firm draws down its credit line, its ability to meet short-term debt obligations will be constrained. Thus, we expect an increased use of credit lines to be negatively related to credit rating upgrades and positive outlooks.

For business position assessment, we control for total assets (Firm Size), firm age (Age), and systematic risk (Beta). Since larger firms generally face lower credit risk, Firm Size is expected to have a positive effect on credit assessments, all else equal. REITs with longer histories may have established a stronger position in the capital market than younger REITs and thus are expected to have lower credit risk, on average. We expect Beta to be negatively related to credit assessments. Finally, we include a peer total return index (Peer_index) to capture the recent market performance of similar REITs. The benchmark SNL return index chosen for each REIT is based upon the company's property type focus. We expect credit assessments to be positively related to recent returns in a REIT's sector.

We include two credit rating indicator variables: $B B B$ - and $B B+. \mathrm{BBB}-$ is the lowest investment-grade credit rating, while $\mathrm{BB}+$ is the highest speculative-grade rating. According to Brown and Riddiough (2003), REITs with unsecured public debt tend to have credit ratings that cluster just above the minimum investment-grade credit rating. We expect REITs with a minimum investment-grade rating (BBB-) to have less incentive to further pay down debt to achieve higher 
ratings. Finally, we include REIT property type fixed effects and year fixed effects in all regression specifications.

\section{Channel Dummies}

As discussed in an earlier section, we propose three possible channels to explain the relation between portfolio transaction activity and perceived credit risk. The Efficient Asset Allocation Hypothesis suggests that the effects of transaction activity on bond yields will partially depend on whether the management team is viewed by the market as being skilled at property transactions as well as on the quality of the properties included in the transactions. We use the firm's stock price premium to per share net asset value (NAV) to capture the perceived quality of the management team and its ability to grow $F F O$ and dividends. ${ }^{9} D \_p o s N A V$ equals one if the REIT was selling at a premium to net asset value over the prior year; that is, if the average price to NAV ratio (share price divided by per share NAV) in year $t-1$ is greater than one. We measure the change in property portfolio quality by the change in return on average assets (ROAA). D_incROAA is set equal to one if the return on average assets increased over the prior year, and zero otherwise.

To test the Proceeds Utilization Hypothesis, we examine the relation between leverage change and the impact of transaction activity on perceived credit quality. If a REIT uses the proceeds from property dispositions to pay down debt, the estimated effect of Disp and Trading on bond yields and credit risk may be less negative, or even positive. $D \_$decLeverage is set equal to one if firm leverage decreased over the prior year, and zero otherwise.

To test the Focus Hypothesis, we calculate a Herfindahl-Hirschman index $(H H I)$ to measure changes in the geographic focus of a firm's property portfolio in year $t-1$. This index is equal to

\footnotetext{
${ }^{9}$ A detailed description of Green Street Advisors NAV pricing model can be found in https://www.greenstreetadvisors.com/
} 
the sum of squared proportion of property portfolio invested in each region, as suggested by John and Ofek (1995) and Capozza and Seguin (1999). According to the U.S. Census Bureau, there are 10 U.S. regions: New England, Middle Atlantic, East North Central, West North Central, South Atlantic, East South Central, West South Central, Mountain, Pacific, and Foreign. The geographic HHI for each REIT in each year is therefore calculated as

$$
\text { HHIgeo }=\sum_{1}^{10} S_{i}^{2}
$$

where $S_{i}$ is the proportion of the property portfolio invested in region $i$.

The weight we use to calculate the index at the end of year $t-1$ is the book value of each REIT's assets invested in each of the 10 regions. If book values are not available, we use the total square footage of properties or the number of rooms/apartments as weights. If none of the above information can be found in a firm's 10-k filings, we use the number of properties in each region as weights. Calculated values of $H H I$ range from 0 to 1 . Values approaching one indicate a high level of geographic focus. The channel dummy ( $D \_$incHHIgeo) is set to one if the change in HHIgeo is positive over the year $t-1$.

Similarly, we construct a property-type HHI in each year for each REIT as:

$$
\text { HHItype }=\sum_{1}^{10} P_{i}^{2}
$$

where $P_{i}$ is the proportion of the property portfolio invested in property type $i$. SNL classifies REITs into 10 property type categories: Multifamily, Industrial, Office, Hotel, Retail, Healthcare, Self-Storage, Manufactured Homes, Restaurant, and Other. We weight by the number of properties in each category. The channel dummy ( $D$ _incHHItype) is set to one if the year-over-year change in HHItype is positive.

To examine the extent to which the impact of transaction activity on credit rating changes and outlooks depends on our conditioning variables, we interact our property transaction variables with 
three channel dummies to examine how transaction activity differentially affects bond spreads and credit rating changes, conditional on different criteria. These interaction variables, as well as the channel dummies, are included along with our other control variables in an augmented specification of equation (6).

\section{Data and Summary Statistics}

We construct our sample from all the listed equity REITs in the U.S. Credit rating changes and ratings outlook data come from the SNL Financial database. This database provides the end-ofyear credit ratings assigned by three rating agencies: S\&P, Moody, and Fitch. We use the long-term S\&P credit ratings in this research because few REITs consistently have ratings from the other two agencies. Property transactions and firm-level accounting data are also from SNL. We construct bond yield spreads using bond yield data from Trade Reporting and Compliance Engine (TRACE). TRACE provides daily transaction data on bond yields starting in July 2002. U.S. Treasury yields are obtained from the FED website. We obtain bond-level information from Mergent Fixed Income Securities Database (FISD). Mergent FISD provides cross sectional descriptive data on corporate bonds, including maturity, coupon, amount offered, etc. Property-level location data used to calculate the Herfindahl-Hirschman index are hand-collected from the $10-\mathrm{k}$ filing forms. Information on the property type focus of each REIT at the beginning of each year is collected from SNL. Time-varying firm-level NAV premiums were provided by Green Street Advisors, LLC.

Our sample size is restricted by the availability of both credit ratings and yield spread data. To be included in our sample, a REIT must have a credit rating assigned by S\&P for at least three consecutive years. We also exclude REITs with missing property transactions data or required accounting data. After merging cross-sectional data from Mergent FISD and yield spread data from 
TRACE, we eliminate REITs without available bond information from either of these two databases. Through this search process, we identify 35 REITs with the necessary data from 2003 to 2012. These 35 firms are used to construct two independent samples for our bond yield and credit rating/outlook analyses. We have 184 firm-year observations in our bond yield sample and 266 observations in our credit rating/outlook sample.

Table 1 displays three sets of summary statistics. The first (panel A) contains the mean, median, minimum, maximum and standard deviation for variables used in both our bond yield and credit rating analyses. Panel B contains the corresponding summary statistics for variables used only in our bond yield analysis, while panel $\mathrm{C}$ displays information on variables used in our analysis of credit rating changes.

[Insert Table 1 about here]

During our sample period, the mean value of $A c q$ (weighted by the book value of total assets) is 11.4 percent. The corresponding average for Disp is 4.9 percent, indicating that REITs were more active buyers than sellers during our sample period. The mean rate of trading intensity is 16.3 percent, but the standard deviation of 15.9 percent indicates significant variation across REITs and over time during our sample period. In our sample, REITs were trading at a premium to NAV in 65.5 percent of the firm-year observations. Slightly less than half of the REITs in our sample experienced an average year-over-year increase in return on average assets. REITs were approximately equally likely to increase or decrease leverage or their geographic concentration from year to year. The mean age of REITs in our sample is approximately 16 years.

The mean (median) bond yield spread is 3.13 (2.25) percentage points (Panel B). Mean leverage is 39 percent but ranges from 17.5 percent to 81.8 percent. The mean value of FFO divided 
by total assets is 5.3 percent. Dividends per share have a sample average of $\$ 1.97$. The mean percentage of available credit lines drawn upon by REITs is 26.8 percent; however, this percentage varies significantly across REITs and time. The credit rating of REITs averaged 9.1, which corresponds to a rating between BBB- and BBB. This is consistent with Brown and Riddiough (2003)'s observation that REITs tend to target a minimum investment-grade credit rating. The average coupon rate on unsecured debt is 6.23 percent and the average remaining term to maturity is almost nine years. The Treasury yield term structure has an average slope of 1.56 percentage points and the mean yield on the closest benchmark Treasury security is 3.23 percent.

As previously discussed, credit ratings on bonds tend to be altered infrequently. In our sample, bond upgrades occurred in 6.5 percent of the firm-years in our sample, which is very similar to the occurrence of a downgrade. Positive or negative outlooks occurred slightly more frequently than actual upgrades or downgrades. The typical REIT increased its leverage (including the amount drawn on credit lines) and decreased its interest coverage ratio modestly over the sample period. However, the average change in FFO and dividends per share were also positive. The average Beta is 0.932 with a standard deviation of 0.202 . In 25.4 percent of our observations, the REIT carried a credit rating of BBB-; in 7.5 percent of the observations, the observed credit rating was $\mathrm{BB}+$.

In Table 2, we summarize the mean value of select variables by credit rating. We group firms into rating categories from A to B- as assigned by the rating agency. Most of the firm-year observations are concentrated around a rating of $\mathrm{BBB}$ (from $\mathrm{BBB}+$ to $\mathrm{BBB}-$ ). REITs with investment-grade ratings (BBB- and above) tend to engage in more acquisitions than firms with speculative-grade ratings ( $\mathrm{BB}+$ and below). However, we observe little difference between the two groups of REITs in disposition activity. In our sample, investment-grade REITs are typically associated with a premium to NAV, while speculative-grade REITs are mostly traded at a discount 
to NAV. More highly rated REITs tend to generate a higher ROAA and use less leverage, with a few exceptions. No clear relation between rating and our focus variables (HHIgeo and HHItype) is observed.

[Insert Table 2 about here]

\section{Empirical Results}

\section{Bond Spread Results}

Table 3 presents the OLS regression results from the estimation of equation (1). Coefficients are reported with t-statistics in parentheses. Error terms are clustered by firm and robust to both heteroskedasticity and within-firm correlation. We first test the effects of property transaction activity on REIT bond yield spreads without channel dummy interactions. The first two columns show the results of these baseline bond yield regressions controlling for firm characteristics. We then add bond-level control variables as well as the level of Treasury yields and the slope of term structure. These augmented regression results are reported in column 3 and column 4.

\section{[Insert Table 3 about here]}

We estimate positive and significant coefficients on both Disp and Trading without bond level controls. More specifically, if dispositions increase by one percentage point, the corporate bond spread rises by 0.12 percentage points. If overall trading activity rises by one percentage point, the bond spread rises by 0.02 percentage point. The estimated coefficient on $A c q$ is not statistically significant. Adding bond specific controls to the regression reduces the magnitude and significance of the transaction activity proxies. 
The estimated coefficients on Leverage and CLD are generally positive and weakly significant, suggesting that higher debt ratios and increased use of credit lines increases credit risk. In column 1 and column 3 , we report a negative and significant association between firm age and yield spread, suggesting older firms are perceived to be less risky. The estimated coefficient on Intcov is consistently positive and significant, which is not consistent with expectations. The estimated coefficients on other firm-level control variables (Firm Size and DPS) are not statistically significant.

With respect to our set of bond control variables, the estimated coefficients on bond rating, coupon rate, issue size, and Treasury rate are not significantly different from zero. However, we find a significant negative relationship between remaining maturity and yield spreads. This contradicts the result in Campbell and Taksler (2003) who find that longer maturities are often associated with higher yield spreads. Chen et al. (2007), on the other hand, find a negative relation between remaining maturity and yield spreads for their speculative-grade bond sample. In our sample, most of the REITs are at the boundary between investment-grade and speculative-grade. Helwege and Turner (1999) argue that higher quality firms are able to issue bonds with longer maturities, which results in a negative relation between yield spread and maturity.

The estimated coefficient of the term structure slope is significantly positive, which also contradicts the findings in Campbell and Taksler (2003). However, Collin-Dufresne et al. (2001) also find significant positive coefficients on the slope of the term structure in their short-maturity (less than nine years) subsamples. In our sample, the median maturity is 8 years. We therefore suspect short-maturity bonds could be driving this result.

The results reported in Table 3 provide some evidence that property transaction activity, particularly property dispositions, are associated with higher bond spreads without conditioning 
on NAV premiums, changes in ROAA, the use of disposition proceeds, or changes in geographic and property-type focus. We next present regression results that include these interaction effects. Table 4 shows the results of OLS regressions testing the Efficient Asset Allocation hypothesis. We employ two dummies variables to construct interaction terms with our property transaction proxies. The first is a positive premium to NAV ( $D \_$posNAV) and the second is an increase in ROAA (D_incROAA) over the prior year. Column 1 and 2 display the results using the NAV dummy variable and columns 3 and 4 present the results using $D \_i n c R O A A$ as our interaction variable.

[Insert Table 4 about here]

Consistent with the results reported in Table 3, the estimated coefficients on Disp and Trading are positive and significant when conditioning on the NAV premium. Moreover, the estimated coefficient on $A c q$ is also positive and highly significant, suggesting that perceived credit risk is increased by heightened acquisition activity when a NAV premium dummy is included. More importantly, the estimated coefficients on the three NAV premium interaction variables are negative and statistically significant. For example, in model [1], the estimated coefficient on $A c q * D \_p o s N A V$ is -5.431 and is significant at the $1 \%$ level. The estimated coefficient on Trading (column [2]) is also positive and significant at the 5 percent level. However, the estimated coefficient on the NAV interaction variable, Trading* $D \_$posNAV is negative and significant and larger in magnitude than the coefficient on Trading. Similarly, dispositions undertaken by REITs selling at a discount to NAV are associated with higher yield spreads; however, this negative trading effect is eliminated if the firm is selling at a premium to NAV. The estimated impact of the control variables are largely unaltered by the inclusion of the channel dummies and interactions 
and are therefore not tabulated to conserve space.

Taken together, these results imply that transaction activity tends to be negatively perceived by creditors when NAV premiums are negative. However, this effect is mitigated if the REIT is trading at a premium to NAV. This result is consistent with our Efficient Asset Allocation hypothesis: REITs that are perceived by the market to have the ability to grow rental income and increase asset values are not penalized by bond investors for active trading of portfolio assets.

We next examine how increases in operating performance (ROAA) over the prior year interact with trading activity in the determination of bond yield spreads. These results reported in columns [3] and [4] of Table 4. When trading activity is conditioned on prior year changes in ROAA, the estimated coefficients on Acq, Disp and Trading are no longer significant and the interaction variables produce no significant explanatory power.

We next estimate equation (6) conditioning on the use of proceeds from dispositions and changes in geographic and property type focus. These results are reported in Table 5. The results for our large set of control variables are again suppressed to conserve space. In the results reported in models [1] and [2], we use D_decLeverage as the channel dummy. We expect the positive relation between bond spreads and transaction activity to be mitigated when REITs use the proceeds from property transactions to pay down debt. However, the estimated coefficient on the interaction term Disp ${ }^{*} D \_$decLeverage is insignificant, which provides no support for the Proceeds Utilization hypothesis. The estimated coefficients on the remaining interaction terms are not significantly different from zero.

In column 3 and 4 of Table 5, we present results from estimating our yield spread regressions while controlling for changes in the firm's geographic focus over the prior year. The estimated coefficients on $A c q *\left(D \_\right.$incHHIgeo $)$and Trading * $\left(D \_\right.$incHHIgeo $)$are positive and significant. No 
significant results are found for the property disposition and focus interactions. These results suggest that acquisitions that increase a REIT's geographic focus are perceived by bondholders as risk increasing. This finding is consistent with the results reported by Mansi and Reeb (2002), who suggest that, although diversification reduces shareholder value, it enhances the position of bondholders by reducing firm risk. Therefore, increased concentration increases stockholders' wealth, but increase creditors' risk exposure. Although not separately tabulated, we find that the effects of transaction activity on bond yields are not related to changes in property type focus (D_incHHItype).

[Insert Table 5 about here]

To summarize the results of our bond yield analysis, we find that property transaction activity is positively and significantly related to REIT bond spreads. This positive relation is largely mitigated when the firm's stock is selling at a premium to its NAV, which is consistent with the Efficient Asset Allocation hypothesis. We find no support for the Proceeds Utilization hypothesis. We also find that an increase in geographic focus generally amplifies the effects of transaction activity on yield spreads. In the following section, we discuss the results obtained using credit rating changes and changes in outlooks as the dependent variable.

\section{Credit Rating Change Results}

Table 6 presents our probit regression results. We employ four different dichotomous dependent variables: upgrade, downgrade, positive outlook, negative outlook. We include both year fixed effects and property-type fixed effects in all specifications. The results reported in columns (1) through (4) suggest trading activity is not predictive of ratings upgrades or downgrades. 


\section{[Insert Table 6 about here]}

In column 5, we find a marginally significant negative relation between property dispositions and the probability of a positive credit rating outlook in the next year. Moreover, we find that the estimated coefficient on all of three transaction proxies are positive and significant in our negative outlook regressions (columns 7 and 8), suggesting that increased transaction activity tends to increase the probability of a negative rating outlook.

The control variable coefficient estimates have the expected signs except the coefficients on C_CLD, Size and Age. We find that an increase in leverage lowers the probability of an upgrade and increases the probability of a negative credit assessment. An increase in the dividend yield is positively related to the probability of a favourable credit assessment. Larger firm is less likely to receive positive outlooks. Older firm has smaller chance to be upgraded in our sample. We find credit assessments are positively related to recent returns in REIT's industry. REITs with higher beta are more likely to be downgraded compared with other REITs.

Table 7 displays the results from estimating our probit regressions while conditioning on the firm's average NAV premium of the prior year. The regressions specifications are otherwise identical to those reported in Table 6, although we suppress the results for the control variables. The estimated coefficients on the transaction proxies (Acq, Disp, and Trading) are negative and highly significant when dependent variable is Upgrade (column 1 and 2), indicating that transaction activity is negatively related to the probability of a ratings upgrade. However, consistent with the bond spread results reported in Table 4, we find the estimated coefficients on the interaction terms are significantly positive when dependent variable is Upgrade. This is consistent with the credit rating agencies removing the "stop sign" when trading activity is 
occurring when NAV premiums are positive. Interestingly, trading activity appears to be unrelated to the probability of a downgrade or positive outlook. However, the results reported in column 7 and 8 suggest that Disp and Trading are predictive of a negative outlook in the following year. These results suggest that transaction activity increases the probability of receiving a negative credit assessment. However, this unfavorable result is mitigated when the REIT is trading at a premium to NAV. These results are consistent with the Efficient Asset Allocation hypothesis.

\section{[Insert Table 7 about here]}

We next replace the NAV premium dummy variable with our increase in ROAA dummy and re-estimate the same set of regressions. We present the results in Table 8, again suppressing the control variable estimates. The estimated coefficients on Acq and Trading are negative and weakly significant in our upgrade regressions. However, the negative effect of trading is not significantly reduced when the REIT experiences an increase in ROAA after property transactions. Overall, conditioning on lagged ROAA has little effect on the remaining results reported in Table 8 .

\section{[Insert Table 8 about here]}

Table 9 reports the results of our probit regressions that test the Proceeds Utilization hypothesis. As shown in column 1, column 2 and column 5, the interaction term on our transaction proxy and the decrease in leverage is positively related to the probability of an upgrade and positive rating outlook in the next year. The estimated coefficient on Disp ${ }^{*} D \_$decLeverage is highly significant and negative, with downgrade as the dependent variable (column 3). The estimated coefficients on transaction variables are not statistically significant. This result implies that when 
a firm's debt ratio decreases after selling off properties, property dispositions are likely to reduce the possibility of being downgraded in the next year. Overall we find some support for the Proceeds Utilization hypothesis; that is, conditional on using proceeds to pay down debt, property transaction activity is favorably or less negatively viewed by credit rating agencies.

\section{[Insert Table 9 about here]}

Finally, we explore the Focus mechanism on credit rating change in Table 10. Consistent with the results in Table 5, we find the interaction of property disposition and an increase in geographic focus is negatively related to the possibility of upgrade at $5 \%$ significance level, and is positively related to the possibility of downgrade at $10 \%$ level. When the dependent variable is rating outlook dummy, the estimated coefficient on interaction term is not observed to be significant. The estimated coefficients on $A c q$ and Trading reported in columns (5) and (7) reinforce our finding that increased transaction activity is viewed negatively by credit rating agencies. Overall, these results are weakly supportive of the Focus hypothesis on bondholder wealth effects; that is, more concentration indicates higher risk and lower credit assessments.

[Insert Table 10 about here]

\section{Conclusion}

Capital recycling through periodic rebalancing of the asset portfolio is of paramount importance for non-finite lived vehicles such as REITs. Most of the previous research examines how real estate acquisitions and dispositions affect the value of shareholders. However, the impact of transaction 
activity on debt holders' wealth has been neglected. In this paper, we try to fill this gap in the literature by investigating the relation between property transactions and creditor's value. We employ bond yield spreads and credit ratings as the proxies for the value of the economic interests of bondholders and other debt holders. We examine the effect of acquisitions, dispositions, as well as overall trading intensity on bond spreads and the probability of a rating change or a positive or negative rating outlook. Our empirical results show that property transaction activity tends to decrease the wealth of creditors.

We further investigate the underlying economic channels that explain the relation between property transaction activity and bondholder's wealth. Motivated by corporate asset transaction literature and press releases on REIT property transactions, we propose three potential mechanisms through which trading activity affects REIT bond yield spreads and credit assessments: Efficient Asset Allocation, Proceeds Utilization, and Focus. Consistent with our hypotheses, we find that the negative effect of property transactions tend to be mitigated when REITs are trading at a premium to NAV, and when they reduce leverage following transactions. The negative effect of transaction activity is strengthened when transactions result in an increase in geographic focus. 


\section{References}

Alexander, G., Benson P. G., \& Kampmeyer, J. (1984). Investigating the valuation effects of announcements of voluntary corporate selloffs. Journal of Finance, 39(2), 503-517.

Altman, E. I., \& Rijken, H. A. (2004). How rating agencies achieve rating stability. Journal of Banking \& Finance, 28(11), 2679-2714.

Amato, J., \& Furfine, C. (2004). Are credit ratings procyclical? Journal of Banking \& Finance, 28(11), 2641-2677.

Berger, P., \& Ofek, E. (1995). Diversification's effect on firm value. Journal of Financial Economics, 37(1), 39-65.

Bessembinder, H., Kahle, K. M., Maxwell, W. F., \& Xu, D. (2008). Measuring abnormal bond performance. Review of Financial Studies, 22(10), 4219-4258.

Brounen, D., Eichholtz, P., \& Ling, D. C. (2007). Trading intensity and real estate performance. Journal of Real Estate Finance and Economics, 35(4), 449-474.

Brown, D. T., \& Riddiough, T. J. (2003). Financing choice and liability structure of real estate investment trusts. Real Estate Economics, 31(3), 313-346.

Campbell, J. Y., \& Taksler, G. B. (2003). Equity volatility and corporate bond yields. Journal of Finance, 58(6), 2321-2350.

Campbell, R. D., Petrova, M., \& Sirmans, C. F. (2003). Wealth effects of diversification and financial deal structuring: evidence from REIT property portfolio acquisitions. Real Estate Economics, 31(3), 347-366.

Campbell, R. D., Petrova, M., \& Sirmans, C. F. (2006). Value creation in REIT property selloffs. Real Estate Economics, 34(2), 329-342.

Capozza, D. R., \& Seguin, P. J. (1999). Focus, transparency and value: the REIT evidence. Real Estate Economics, 27(4), 587-619.

Chen, L., Lesmond, D. A., \& Wei, J. (2007). Corporate yield spreads and bond liquidity. Journal of Finance, 62(1), 119-149.

Cheng, M., \& Neamtiu, M. (2009). An empirical analysis of changes in credit rating properties: timeliness, accuracy and volatility. Journal of Accounting and Economics, 47(1-2), 108-130.

Collin-Dufresn, P., Goldstein, R. S., \& Martin, J. S. (2001). The determinants of credit spread changes. Journal of Finance, 56(6), 2177-2207.

Comment, R., \& Jarrell, G. A. (1995). Corporate focus and stock returns. Journal of Financial Economics, 37(1), 67-87.

Datta, S., \& Iskandar - Datta, M. E. (1996). Who gains from corporate asset sales?. Journal of Financial Research, 19(1), 41-58. 
Datta, S., Iskandar-Datta, M., \& Raman, K. (2003). Value creation in corporate asset sales: the role of managerial performance and lender monitoring. Journal of Banking \& Finance, 27(2), $351-375$.

Demirci, I., Eichholtz, P., \& Yönder, E. (2018). Corporate diversification and the cost of debt. Journal of Real Estate Finance and Economics. https://doi.org/10.1007/s11146-017-9645-9.

Feng, Z., Ghosh, C., \& Sirmans, C. F. (2007). On the capital structure of real estate investment trusts (REITs). Journal of Real Estate Finance and Economics, 34(1), 81-105.

Franco, F., Urcan, O., \& Vasvari, F. P. (2015). Corporate diversification and the cost of debt: the role of segment disclosures. The Accounting Review, 91(4), 1139-1165.

Giacomini, E., Ling, D. C., \& Naranjo, A. (2017). REIT leverage and return performance: keep your eye on the target. Real Estate Economics, 45(4), 930-978.

Glascock, J. L., Davidson III, W. N., \& Sirmans, C. F. (1991). The gains from corporate selloffs: the case of real estate assets. Real Estate Economics, 19(4), 567-582.

Helwege, J., \& Turner, C. M. (1999). The slope of the credit yield curve for speculative - grade issuers. Journal of Finance, 54(5), 1869-1884.

Hite, G. L., Owers, J. E., \& Rogers, R. C. (1987). The market for interfirm asset sales: partial selloffs and total liquidations. Journal of Financial Economics, 18(2), 229-252.

Jain, P. C. (1985). The effect of voluntary sell - off announcements on shareholder wealth. Journal of Finance, 40(1), 209-224.

Jensen, M. C., \& Meckling, W. H. (1976). Theory of the firm: managerial behavior, agency costs and ownership structure. Journal of Financial Economics, 3(4), 305-360.

John, K., \& Ofek, E. (1995). Asset sales and increase in focus. Journal of Financial Economics, 37(1), 105-126.

Kisgen, D. J. (2006). Credit ratings and capital structure. Journal of Finance, 61(3), 1035-1072.

Lang, L. H., \& Stulz, R. M. (1994). Tobin's q, corporate diversification, and firm performance. Journal of Political Economy, 102(6), 1248-1280.

Lang, L., Poulsen, A., \& Stulz, R. (1995). Asset sales, firm performance, and the agency costs of managerial discretion. Journal of Financial Economics, 37(1), 3-37.

Li, Q., Chow, Y. L., \& Ong, S. E. (2014). Do changes in credit ratings of REITs affect their capital structure decisions?. Journal of Property Research, 31(3), 264-285.

Ling, D. C., Ooi, J. T., \& Xu, R. (2016). Asset growth and stock performance: evidence from REITs. Real Estate Economics. https://doi.org/10.1111/1540-6229.12186.

Löffler, G. (2005). Avoiding the rating bounce: Why rating agencies are slow to react to new information. Journal of Economic Behavior \& Organization, 56(3), 365-381. 
Mansi, S. A., \& Reeb, D. M. (2002). Corporate diversification: what gets discounted?. Journal of Finance, 57(5), 2167-2183.

McIntosh, W., Ott, S. H., \& Liang, Y. (1995). The wealth effects of real estate transactions: the case of REITs. Journal of Real Estate Finance and Economics, 10(3), 299-307.

Myers, S. C. (1977). Determinants of corporate borrowing. Journal of Financial Economics, 5(2), $147-175$.

Ong, S. E., Ooi, J. T., \& Kawaguichi, Y. (2011). Seasoned equity issuance by Japan and Singapore REITs. Journal of Real Estate Finance and Economics, 43(1-2), 205-220.

Ooi, J. T., Ong, S. E., \& Li, L. (2010). An analysis of the financing decisions of REITs: the role of market timing and target leverage. Journal of Real Estate Finance and Economics, 40(2), $130-160$.

Ooi, J. T., Ong, S. E., \& Neo, P. H. (2011). The wealth effects of property acquisitions: evidence from Japanese and Singaporean REITs. Real Estate Economics, 39(3), 487-505.

Standard \& Poor's. (2004). Industrials: rating criteria for U.S. REITs and REOCs. http://www.businesswire.com/news/home/20040512005694/en/SP-Announces-RatingCriteria-U.S.-REITs-REOCs

Warusawitharana, M. (2008). Corporate asset purchases and sales: theory and evidence. Journal of Financial Economics, 87(2), 471-497. 
Table 1 Summary Statistics

\begin{tabular}{|c|c|c|c|c|c|}
\hline \multicolumn{6}{|c|}{ Panel A: Common Variables in Both Tests } \\
\hline & Mean & Min & $\mathrm{P} 50$ & Max & $\mathrm{Sd}$ \\
\hline$A c q$ & 0.114 & 0 & 0.073 & 0.871 & 0.14 \\
\hline Disp & 0.049 & 0 & 0.027 & 0.499 & 0.064 \\
\hline Trading & 0.163 & 0 & 0.116 & 0.94 & 0.159 \\
\hline D_posNAV & 0.655 & 0 & 1 & 1 & 0.477 \\
\hline D_incROAA & 0.469 & 0 & 0 & 1 & 0.5 \\
\hline D_decLeverage & 0.505 & 0 & 1 & 1 & 0.501 \\
\hline D_incHHIgeo & 0.517 & 0 & 1 & 1 & 0.501 \\
\hline D_incHHItype & 0.311 & 0 & 0 & 1 & 0.464 \\
\hline Firm Size & 15.483 & 13.828 & 15.357 & 17.122 & 0.745 \\
\hline Age & 15.905 & 0 & 14 & 42 & 7.197 \\
\hline \multicolumn{6}{|c|}{ Panel B: Variables only in Spread Tests } \\
\hline & Mean & Min & P50 & Max & $\mathrm{Sd}$ \\
\hline Spread $(\%)$ & 3.128 & -4.325 & 2.249 & 29.108 & 3.516 \\
\hline Leverage(\%) & 39.293 & 17.506 & 37.89 & 81.819 & 10.532 \\
\hline Intcov & 2.982 & 0.658 & 2.922 & 6.069 & 0.814 \\
\hline FFO & 0.053 & -0.012 & 0.053 & 0.099 & 0.016 \\
\hline$D P S$ & 1.965 & 0 & 1.76 & 8.7 & 1.14 \\
\hline$C L D(\%)$ & 26.729 & 0 & 23.303 & 91.049 & 23.474 \\
\hline Rating & 9.154 & 6 & 9 & 14 & 1.387 \\
\hline Coupon $(\times 10)$ & 0.623 & 0.362 & 0.615 & 0.9 & 0.12 \\
\hline Issue size & 12.118 & 10.127 & 12.206 & 13.319 & 0.648 \\
\hline Maturity & 8.953 & 2 & 8 & 24 & 4.568 \\
\hline Termstr & 1.557 & 0.031 & 1.984 & 2.669 & 0.997 \\
\hline Treasury & 3.234 & 0.272 & 3.501 & 5.157 & 1.478 \\
\hline \multicolumn{6}{|c|}{ Panel C: Variables only in Rating Change Tests } \\
\hline & Mean & Min & $\mathrm{P} 50$ & $\operatorname{Max}$ & $\mathrm{Sd}$ \\
\hline Upgrade & 0.065 & 0 & 0 & 1 & 0.246 \\
\hline Downgrade & 0.063 & 0 & 0 & 1 & 0.242 \\
\hline Positive & 0.078 & 0 & 0 & 1 & 0.268 \\
\hline Negative & 0.08 & 0 & 0 & 1 & 0.271 \\
\hline C_leverage & 0.025 & -0.96 & -0.028 & 3.176 & 0.287 \\
\hline C_intcov & -0.017 & -9.58 & -0.011 & 2.516 & 0.579 \\
\hline$C_{-} F F O$ & 0.225 & -8.082 & -0.007 & 78.199 & 4.149 \\
\hline C_DPS & 0.093 & -1 & 0.011 & 4.8 & 0.592 \\
\hline$C_{-} C L D$ & 0.262 & -1 & -0.016 & 14 & 1.816 \\
\hline Peer_index & 210.505 & 17.253 & 184.317 & 947.101 & 146.795 \\
\hline Beta & 0.932 & 0.579 & 0.895 & 1.741 & 0.202 \\
\hline$B B B-$ & 0.254 & 0 & 0 & 1 & 0.436 \\
\hline$B B+$ & 0.075 & 0 & 0 & 1 & 0.264 \\
\hline
\end{tabular}


Note: Table 1 provides summary statistics for the sample of 35 REITs used in this study during 2003 to 2012. There are 184 firm-year observations in the bond test and 266 firm-year observations in the credit assessment test. We report sample mean (Mean), minimum value (Min), median value (P50), maximum value (Max), and standard deviation (Sd).

Panel A presents the summary statistics for the variables used in both bond and credit rating/outlook tests. Acq is equal to the aggregate contractual gross sales price of properties bought during year t- 1 , divided by average value of total assets during year t-1. Disp is equal to the aggregate contractual gross sales price of sold properties during year t-1, divided by average total asset value during the year. Trading is the sum of Acq and Disp. D_posNAV equals one if the REIT was selling at a premium to net asset value over the period of property transaction activity; that is, if the average price to NAV ratio (share price divided by per share NAV) in year $t-1$ is greater than one. $D \_i n c R O A A$ is set equal to one if the return on average assets increased over the prior year, and zero otherwise. D_decLeverage is set equal to one if firm leverage decreased over the prior year, and zero otherwise. D_incHHIgeo is set to one if the change in geographic concentration level (measured by Herfindahl-Hirschman index) is positive over the year $t$-1, and zero otherwise. D_incHHItype is set to one if the year-over-year change in property-type concentration level is positive, and zero otherwise. Firm Size is the natural logarithm of total assets. Age is the number of years since the firm's IPO.

Panel B presents the summary statistics for the variables used only in bond yield spread test. Spread is the average daily difference between the yield to maturity on the bond in the year $\mathrm{t}$ and the yield on the benchmark U.S. Treasury with the closest maturity in the same year. Intcov is interest coverage ratio, calculated by dividing earnings before interest and taxes by interest expenses for the same period. $F F O$ is funds from operation divided by total assets. DPS is dividends per share. CLD is the percentage amount drawn on the firm's credit line(s) divided by the total available credit line. Rating is the credit rating issued by S\&P, Coupon is the bond's coupon interest rate multiplied by 10, Issue Size is the natural logarithm of the bond offer amount, and Maturity is the number of years to maturity of the bond. Treasury is the closest benchmark Treasury rate. Termstr is the difference between the 10-year and 2-year Treasury rates.

Panel $\mathrm{C}$ describes the summary statistics for the variables used only in credit rating change/outlook test. Upgrade is set to one if firm is upgraded sometime during the year $\mathrm{t}$, and zero otherwise. Downgrade is set to one if firm is downgraded during the year $\mathrm{t}$, and zero otherwise. Positive/Negative equals one if firm is assigned a positive/negative credit rating outlook in year $t$ by $\mathrm{S} \& \mathrm{P}$, and zero otherwise. C_Leverage, $C_{-}$Intcov, $C_{-} F F O, C_{-} D P S$, and $C_{-} C L D$ are the year-over-year change in leverage, interest coverage, funds from operations divided by total assets, dividend per share, and credit line drawn as percentage of total available credit line, respectively. Peer_index is a peer total return index that captures the recent market performance of similar REITs. Beta is a measure of systematic risk calculated by the past one-year's stock return. $B B B$ - and $B B+$ are both dummy variables, which are set to one if the credit rating is $\mathrm{BBB}-$ and $\mathrm{BB}+$, respectively. 
Table 2 Sample Summary by Credit Rating

\begin{tabular}{lrrrrrrrrr}
\hline Rating & $\mathrm{N}$ & Acq & Disp & Trading & NAVprem & ROAA & Leverage(\%) & HHIgeo & HHItype \\
\hline A & 2 & 0.122 & 0.033 & 0.154 & 0.186 & 5.213 & 36.563 & 0.328 & 0.710 \\
A- & 16 & 0.132 & 0.058 & 0.189 & 0.083 & 5.500 & 29.330 & 0.210 & 0.951 \\
BBB+ & 43 & 0.061 & 0.039 & 0.099 & 0.064 & 3.735 & 36.570 & 0.284 & 0.836 \\
BBB & 95 & 0.114 & 0.065 & 0.179 & 0.042 & 3.377 & 39.111 & 0.336 & 0.869 \\
BBB- & 64 & 0.095 & 0.047 & 0.142 & 0.026 & 2.646 & 41.284 & 0.367 & 0.920 \\
BB+ & 17 & 0.129 & 0.058 & 0.188 & -0.037 & 3.233 & 44.044 & 0.287 & 0.955 \\
BB & 12 & 0.057 & 0.053 & 0.111 & -0.101 & 1.297 & 48.732 & 0.216 & 0.993 \\
BB- & 6 & 0.031 & 0.056 & 0.087 & -0.193 & 0.692 & 54.877 & 0.178 & 0.948 \\
B+ & 8 & 0.046 & 0.037 & 0.083 & -0.237 & -0.005 & 63.943 & 0.374 & 0.933 \\
B & 2 & 0.035 & 0.147 & 0.182 & -0.335 & 4.504 & 67.453 & 0.611 & 1.000 \\
B- & 1 & 0.042 & 0.037 & 0.079 & 2.376 & -8.856 & 56.695 & 0.179 & 1.000 \\
& & & & & & & 3.098 & 40.747 & 0.319 \\
Total & 266 & 0.096 & 0.054 & 0.15 & 0.028 & 390 & 0.895 \\
\hline
\end{tabular}

Note: Table 2 summarizes the number of observations and the average value of select variables by credit ratings. NAVprem is the value of NAV premium, calculated by stock price divided by NAV per share minus one. ROAA is the return on average assets, calculated by net income divided by total assets. HHIgeo is the sum of squared proportion of property portfolio invested in each region. HHItype is the sum of squared proportion of property portfolio invested in each property type. 
Table 3 Property Transactions and Bond Yield Spreads: Overall

\begin{tabular}{|c|c|c|c|c|}
\hline \multirow{2}{*}{$\begin{array}{l}\text { Dependent variable } \\
\text { Model\# }\end{array}$} & \multicolumn{4}{|c|}{ Spread } \\
\hline & [1] & [2] & [3] & [4] \\
\hline \multirow[t]{2}{*}{ Acq } & 0.791 & & -0.017 & \\
\hline & $(0.89)$ & & $(-0.02)$ & \\
\hline \multirow[t]{2}{*}{ Disp } & $11.607 * *$ & & $8.896^{*}$ & \\
\hline & $(2.11)$ & & (1.69) & \\
\hline \multirow[t]{2}{*}{ Trading } & & $2.123 * * *$ & & 1.026 \\
\hline & & $(2.85)$ & & $(1.56)$ \\
\hline \multirow[t]{2}{*}{ Firm Size } & 0.089 & 0.139 & 0.449 & 0.387 \\
\hline & $(0.24)$ & $(0.32)$ & $(0.88)$ & $(0.77)$ \\
\hline \multirow[t]{2}{*}{ Leverage } & $0.080^{*}$ & $0.079 *$ & 0.055 & $0.056^{*}$ \\
\hline & (1.98) & (1.98) & (1.69) & (1.72) \\
\hline \multirow[t]{2}{*}{ Age } & $-0.044 * *$ & -0.032 & $-0.029 *$ & -0.019 \\
\hline & $(-2.47)$ & $(-1.66)$ & $(-1.84)$ & $(-0.95)$ \\
\hline \multirow[t]{2}{*}{ Intcov } & $0.895^{* *}$ & $0.884^{* *}$ & $0.901 * *$ & $0.921 * *$ \\
\hline & $(2.22)$ & $(2.38)$ & $(2.45)$ & $(2.63)$ \\
\hline \multirow[t]{2}{*}{ FFO } & 37.222 & 38.125 & 31.155 & 27.180 \\
\hline & $(1.24)$ & $(1.26)$ & $(0.95)$ & $(0.85)$ \\
\hline \multirow[t]{2}{*}{$D P S$} & -0.297 & -0.326 & 0.041 & 0.025 \\
\hline & $(-1.55)$ & $(-1.68)$ & $(0.18)$ & $(0.12)$ \\
\hline \multirow[t]{2}{*}{$C L D$} & 0.009 & $0.010^{*}$ & $0.011^{*}$ & $0.012 *$ \\
\hline & $(1.66)$ & (1.83) & $(1.75)$ & (1.92) \\
\hline \multirow[t]{2}{*}{ Rating } & & & 0.387 & 0.284 \\
\hline & & & $(1.26)$ & (1.10) \\
\hline \multirow[t]{2}{*}{ Coupon } & & & 2.369 & 2.929 \\
\hline & & & (1.29) & (1.68) \\
\hline \multirow[t]{2}{*}{ Issue size } & & & -0.681 & -0.694 \\
\hline & & & $(-1.62)$ & $(-1.59)$ \\
\hline \multirow[t]{2}{*}{ Maturity } & & & $-0.280 * * *$ & $-0.312 * * *$ \\
\hline & & & $(-3.37)$ & $(-3.52)$ \\
\hline \multirow[t]{2}{*}{ Termstr } & & & $1.109^{* * *}$ & $1.172 * * *$ \\
\hline & & & $(3.61)$ & $(3.55)$ \\
\hline \multirow[t]{2}{*}{ Treasury } & & & 0.663 & 0.733 \\
\hline & & & $(1.27)$ & (1.39) \\
\hline \multirow[t]{2}{*}{ Constant } & -5.023 & -5.538 & -7.821 & -5.959 \\
\hline & $(-0.62)$ & $(-0.63)$ & $(-0.84)$ & $(-0.63)$ \\
\hline Year FE & Y & Y & $\mathrm{Y}$ & Y \\
\hline Ptype FE & Y & Y & Y & Y \\
\hline
\end{tabular}




\begin{tabular}{lcccc} 
Observations & 184 & 184 & 184 & 184 \\
R-squared & 0.706 & 0.691 & 0.739 & 0.730 \\
\hline
\end{tabular}

Note: Table 3 presents the OLS estimation result of equation (1). The dependent variable is Spread. Each estimation includes year fixed effects and property-type fixed effects. Based on the corresponding t-statistic in parentheses, $* * *, * *$, and $*$ indicate statistical significance for the estimated coefficient at the $1 \%, 5 \%$, and $10 \%$ levels of confidence, respectively. Error terms are clustered by firm and robust to both heteroskedasticity and within-firm correlation. 
Table 4 Property Transactions and Bond Yield Spread: Testing Efficient Asset Allocation

\begin{tabular}{|c|c|c|c|c|}
\hline \multirow{3}{*}{$\begin{array}{l}\text { Testing Channel: } \\
\text { Channel Dummy Variables: } \\
\text { Model\# }\end{array}$} & \multicolumn{4}{|c|}{ Efficient Asset Allocation } \\
\hline & \multicolumn{2}{|c|}{ Positive Premium to NAV } & \multicolumn{2}{|c|}{ Increase in ROAA } \\
\hline & {$[1]$} & {$[2]$} & [3] & {$[4]$} \\
\hline$A c q$ & $\begin{array}{c}3.855^{* * *} \\
(3.39)\end{array}$ & & $\begin{array}{l}0.337 \\
(0.39)\end{array}$ & \\
\hline Acq*Channel Dummy & $\begin{array}{c}-5.431 * * * \\
(-3.70)\end{array}$ & & $\begin{array}{l}-0.635 \\
(-0.42)\end{array}$ & \\
\hline Disp & $\begin{array}{c}18.328 * \\
(1.74)\end{array}$ & & $\begin{array}{l}12.892 \\
(1.49)\end{array}$ & \\
\hline Disp*Channel Dummy & $\begin{array}{c}-20.197 * \\
(-1.79)\end{array}$ & & $\begin{array}{c}-14.568 \\
(-1.40)\end{array}$ & \\
\hline Trading & & $\begin{array}{c}6.711 * * \\
(2.24)\end{array}$ & & $\begin{array}{l}2.131 \\
(1.46)\end{array}$ \\
\hline Trading*Channel Dummy & & $\begin{array}{c}-8.424 * * \\
(-2.35)\end{array}$ & & $\begin{array}{l}-3.093 \\
(-1.06)\end{array}$ \\
\hline Channel Dummy & $\begin{array}{c}2.003 * * \\
(2.06)\end{array}$ & $\begin{array}{c}1.522 * * \\
(2.10)\end{array}$ & $\begin{array}{l}0.920 \\
(1.22)\end{array}$ & $\begin{array}{l}0.524 \\
(0.90)\end{array}$ \\
\hline Constant & $\begin{array}{c}-11.682 \\
(-0.91)\end{array}$ & $\begin{array}{l}-8.343 \\
(-0.71)\end{array}$ & $\begin{array}{l}-11.344 \\
(-1.22)\end{array}$ & $\begin{array}{l}-7.447 \\
(-0.77)\end{array}$ \\
\hline Year FE & Y & $\mathrm{Y}$ & Y & $\mathrm{Y}$ \\
\hline Ptype FE & Y & $\mathrm{Y}$ & Y & $\mathrm{Y}$ \\
\hline Observations & 149 & 149 & 184 & 184 \\
\hline$R$-squared & 0.765 & 0.751 & 0.752 & 0.734 \\
\hline
\end{tabular}

Note: Table 4 reports the OLS estimation result of equation (5). We test the Efficient Asset Allocation hypothesis using $D \_p o s N A V$ and $D \_i n c R O A A$ as the channel dummy variables. The dependent variable is Spread. Each estimation includes year fixed effects and property-type fixed effects. Based on the corresponding t-statistic in parentheses, $* * *, * *$, and * indicate statistical significance for the estimated coefficient at the $1 \%, 5 \%$, and $10 \%$ levels of confidence, respectively. Error terms are clustered by firm and robust to both heteroskedasticity and within-firm correlation. Control variables (same as in Table 3) are not shown in the table but are included in every estimation. 
Table 5 Property Transactions and Bond Yield Spread: Testing Proceeds Utilization \& Focus

\begin{tabular}{|c|c|c|c|c|}
\hline \multirow{3}{*}{$\begin{array}{l}\text { Testing Channel: } \\
\text { Channel Dummy Variables: } \\
\text { Model\# }\end{array}$} & \multicolumn{2}{|c|}{ Proceeds Utilization } & \multicolumn{2}{|c|}{ Focus } \\
\hline & \multicolumn{2}{|c|}{ Decrease in leverage } & \multicolumn{2}{|c|}{ Increase in geographical focus } \\
\hline & [1] & [2] & [3] & [4] \\
\hline$A c q_{t-1}$ & $\begin{array}{l}0.837 \\
(0.68)\end{array}$ & & $\begin{array}{l}-1.542 \\
(-1.24)\end{array}$ & \\
\hline Acq*Channel Dummy & $\begin{array}{l}-1.715 \\
(-0.91)\end{array}$ & & $\begin{array}{c}4.249^{* *} \\
(2.60)\end{array}$ & \\
\hline $\operatorname{Disp}_{t-1}$ & $\begin{array}{l}13.431 \\
(1.49)\end{array}$ & & $\begin{array}{l}3.171 \\
(1.03)\end{array}$ & \\
\hline Disp*Channel Dummy & $\begin{array}{r}-13.982 \\
(-1.45)\end{array}$ & & $\begin{array}{l}1.922 \\
(0.41)\end{array}$ & \\
\hline Trading $_{t-1}$ & & $\begin{array}{l}2.409 \\
(1.44)\end{array}$ & & $\begin{array}{l}-0.800 \\
(-0.73)\end{array}$ \\
\hline Trading*Channel Dummy & & $\begin{array}{l}-3.635 \\
(-1.32)\end{array}$ & & $\begin{array}{c}3.632 * * \\
(2.46)\end{array}$ \\
\hline Channel Dummy & $\begin{array}{l}0.713 \\
(0.90)\end{array}$ & $\begin{array}{l}0.345 \\
(0.49)\end{array}$ & $\begin{array}{c}-1.166^{* *} \\
(-2.64)\end{array}$ & $\begin{array}{c}-1.202^{* *} \\
(-2.51)\end{array}$ \\
\hline Constant & $\begin{array}{l}-6.587 \\
(-0.87)\end{array}$ & $\begin{array}{l}-6.069 \\
(-0.70)\end{array}$ & $\begin{array}{l}-0.534 \\
(-0.05)\end{array}$ & $\begin{array}{l}1.991 \\
(0.19)\end{array}$ \\
\hline Year FE & $\mathrm{Y}$ & $\mathrm{Y}$ & $\mathrm{Y}$ & $\mathrm{Y}$ \\
\hline Ptype FE & $\mathrm{Y}$ & $\mathrm{Y}$ & $\mathrm{Y}$ & $\mathrm{Y}$ \\
\hline Observations & 184 & 184 & 131 & 131 \\
\hline$R$-squared & 0.752 & 0.736 & 0.777 & 0.775 \\
\hline
\end{tabular}

Note: Table 5 reports the OLS estimation result of equation (5). We test the Proceeds Utilization and Focus hypothesis using D_decLeverage and D_incHHIgeo as the channel dummy variables. The dependent variable is Spread. Each estimation includes year fixed effects and property-type fixed effects. Based on the corresponding t-statistic in parentheses, ${ }^{* * *}, * *$, and $*$ indicate statistical significance for the estimated coefficient at the $1 \%, 5 \%$, and $10 \%$ levels of confidence, respectively. Error terms are clustered by firm and robust to both heteroskedasticity and within-firm correlation. Control variables (same as in Table 3) are not shown in the table but are included in every estimation. 
Table 6 Property Transactions and Credit Rating Changes: Overall

\begin{tabular}{|c|c|c|c|c|c|c|c|c|}
\hline \multirow{2}{*}{$\begin{array}{l}\text { Dependent variable: } \\
\text { Model\# }\end{array}$} & Upgrade & Upgrade & Downgrade & Downgrade & Positive & Positive & Negative & Negative \\
\hline & (1) & (2) & (3) & (4) & (5) & (6) & (7) & $(8)$ \\
\hline \multirow[t]{2}{*}{ Acq } & -1.554 & & 1.191 & & 0.981 & & $1.668^{* *}$ & \\
\hline & $(-1.46)$ & & $(1.29)$ & & $(1.13)$ & & $(2.21)$ & \\
\hline \multirow[t]{2}{*}{ Disp } & -0.179 & & -1.639 & & $-7.821^{*}$ & & $5.102 * * *$ & \\
\hline & $(-0.06)$ & & $(-0.73)$ & & $(-1.83)$ & & $(3.07)$ & \\
\hline \multirow[t]{2}{*}{ Trading } & & -1.335 & & 0.674 & & 0.155 & & $2.363 * * *$ \\
\hline & & $(-1.35)$ & & $(0.88)$ & & $(0.15)$ & & $(3.60)$ \\
\hline \multirow[t]{2}{*}{ C_leverage } & $-1.738 * *$ & $-1.748 * * *$ & $1.402 *$ & $1.494^{*}$ & -0.751 & -0.581 & $1.665^{* *}$ & $1.481^{*}$ \\
\hline & $(-2.54)$ & $(-2.58)$ & $(1.67)$ & $(1.76)$ & $(-1.18)$ & $(-0.94)$ & $(2.04)$ & $(1.86)$ \\
\hline \multirow[t]{2}{*}{ C_intcov } & 0.223 & 0.222 & -0.303 & -0.293 & 0.039 & 0.042 & 0.713 & 0.746 \\
\hline & $(1.52)$ & $(1.45)$ & $(-1.33)$ & $(-1.22)$ & $(0.26)$ & $(0.26)$ & (1.07) & $(1.47)$ \\
\hline \multirow[t]{2}{*}{$C_{-} F F O$} & 0.098 & 0.089 & $-0.174 * *$ & $-0.157^{*}$ & 0.202 & 0.190 & 0.193 & 0.133 \\
\hline & $(0.80)$ & $(0.82)$ & $(-2.19)$ & $(-1.94)$ & $(1.26)$ & $(1.31)$ & (1.09) & $(0.84)$ \\
\hline \multirow[t]{2}{*}{ C_DPS } & $0.694 *$ & $0.714^{*}$ & $-1.631 * * *$ & $-1.650 * * *$ & $1.415 * * *$ & $1.171 * * *$ & -0.254 & -0.167 \\
\hline & $(1.75)$ & $(1.79)$ & $(-3.32)$ & $(-3.19)$ & $(3.44)$ & $(2.85)$ & $(-0.85)$ & $(-0.55)$ \\
\hline \multirow[t]{2}{*}{ C_CLD } & $0.125^{*}$ & $0.122^{*}$ & 0.093 & 0.094 & 0.053 & 0.067 & $-0.220 * *$ & $-0.237 * *$ \\
\hline & $(1.84)$ & $(1.79)$ & $(1.45)$ & $(1.46)$ & $(1.01)$ & $(1.43)$ & $(-2.26)$ & $(-2.27)$ \\
\hline \multirow[t]{2}{*}{ Firm Size } & -0.114 & -0.108 & -0.231 & -0.235 & $-0.350 * *$ & $-0.295^{*}$ & 0.110 & 0.115 \\
\hline & $(-0.46)$ & $(-0.44)$ & $(-1.56)$ & $(-1.63)$ & $(-2.16)$ & $(-1.75)$ & $(0.64)$ & $(0.69)$ \\
\hline \multirow[t]{2}{*}{ Age } & $-0.059 * *$ & $-0.057 * *$ & 0.002 & 0.000 & 0.009 & 0.006 & 0.012 & 0.012 \\
\hline & $(-2.30)$ & $(-2.33)$ & $(0.10)$ & $(0.00)$ & $(0.34)$ & $(0.23)$ & $(0.57)$ & $(0.63)$ \\
\hline \multirow[t]{2}{*}{ Peer_index } & $0.004 * *$ & $0.003 * *$ & 0.002 & 0.002 & 0.002 & $0.002 *$ & $-0.006 * *$ & $-0.006^{* *}$ \\
\hline & (1.98) & (1.98) & $(0.73)$ & $(0.83)$ & $(1.30)$ & $(1.65)$ & $(-2.33)$ & $(-2.38)$ \\
\hline \multirow[t]{2}{*}{ Beta } & 0.204 & 0.235 & $3.917 * * *$ & $3.644 * * *$ & -1.112 & -1.431 & 1.351 & 1.597 \\
\hline & $(0.20)$ & $(0.24)$ & $(4.43)$ & $(4.27)$ & $(-1.17)$ & $(-1.46)$ & $(1.26)$ & $(1.45)$ \\
\hline \multirow[t]{2}{*}{$B B B-$} & -0.702 & -0.673 & $-0.993 *$ & $-1.044 * *$ & -0.044 & -0.140 & 0.253 & 0.361 \\
\hline & $(-1.19)$ & $(-1.20)$ & $(-1.87)$ & $(-2.03)$ & $(-0.15)$ & $(-0.51)$ & $(0.72)$ & (1.04) \\
\hline$B B+$ & 0.139 & 0.120 & 0.269 & 0.267 & -0.691 & -0.320 & -0.189 & -0.046 \\
\hline
\end{tabular}




\begin{tabular}{lcccccccc} 
& $(0.33)$ & $(0.28)$ & $(0.53)$ & $(0.54)$ & $(-1.22)$ & $(-0.60)$ & $(-0.35)$ & $(-0.08)$ \\
Constant & -0.017 & -0.181 & -3.946 & -3.360 & $4.447^{*}$ & 3.926 & -4.837 & -5.278 \\
& $(-0.00)$ & $(-0.05)$ & $(-1.37)$ & $(-1.16)$ & $(1.73)$ & $(1.50)$ & $(-1.47)$ & $(-1.58)$ \\
Year FE & & & & & & & \\
Ptype FE & $\mathrm{Y}$ & $\mathrm{Y}$ & $\mathrm{Y}$ & $\mathrm{Y}$ & $\mathrm{Y}$ & $\mathrm{Y}$ & $\mathrm{Y}$ \\
Observations & $\mathrm{Y}$ & $\mathrm{Y}$ & $\mathrm{Y}$ & $\mathrm{Y}$ & $\mathrm{Y}$ & $\mathrm{Y}$ & $\mathrm{Y}$ & $\mathrm{Y}$ \\
Pseudo R-squared & $\mathrm{Y}$ & 266 & 266 & 266 & 266 & 266 & 266 & 266 \\
\hline
\end{tabular}

Note: Table 6 reports the probit regression result of equation (6). We employ four different dichotomous dependent variables: upgrade, downgrade, positive outlook, negative outlook. Each estimation includes year fixed effects and property-type fixed effects. Based on the corresponding t-statistic in parentheses, ${ }^{* *}, * *$, and $*$ indicate statistical significance for the estimated coefficient at the $1 \%, 5 \%$, and $10 \%$ levels of confidence, respectively. Error terms are clustered by firm and robust to both heteroskedasticity and within-firm correlation. 
Table 7 Property Transaction and Credit Rating Change: Testing Efficient Asset Allocation (NAV premium)

\begin{tabular}{|c|c|c|c|c|c|c|c|c|}
\hline \multirow{2}{*}{$\begin{array}{l}\text { Dependent variable: } \\
\text { Model\# }\end{array}$} & Upgrade & Upgrade & Downgrade & Downgrade & Positive & Positive & Negative & Negative \\
\hline & (1) & (2) & (3) & (4) & $(5)$ & (6) & (7) & $(8)$ \\
\hline \multirow[t]{2}{*}{$A c q$} & $-16.859 * * *$ & & 1.221 & & $1.975^{*}$ & & 1.162 & \\
\hline & $(-2.59)$ & & $(1.25)$ & & $(1.81)$ & & $(0.76)$ & \\
\hline \multirow{2}{*}{$A c q * D \_p o s N A V$} & $10.919^{*}$ & & -0.863 & & 0.193 & & $-3.754 * *$ & \\
\hline & $(1.66)$ & & $(-0.58)$ & & $(0.14)$ & & $(-1.98)$ & \\
\hline \multirow[t]{2}{*}{ Disp } & $-18.136^{* *}$ & & -2.027 & & -4.716 & & $6.898 * * *$ & \\
\hline & $(-2.16)$ & & $(-0.75)$ & & $(-0.85)$ & & $(3.13)$ & \\
\hline \multirow[t]{2}{*}{ Disp $* D \_p o s N A V$} & $19.710^{* *}$ & & 1.882 & & -11.612 & & $-8.909 * *$ & \\
\hline & $(2.42)$ & & $(0.51)$ & & $(-1.37)$ & & $(-2.22)$ & \\
\hline \multirow[t]{2}{*}{ Trading } & & $-16.778 * *$ & & 0.304 & & 0.554 & & $2.514^{* *}$ \\
\hline & & $(-2.52)$ & & $(0.33)$ & & $(0.51)$ & & $(2.33)$ \\
\hline \multirow[t]{2}{*}{ Trading $* D \_p o s N A V$} & & $12.511^{* *}$ & & 0.028 & & 0.611 & & $-3.328 * *$ \\
\hline & & $(2.05)$ & & $(0.02)$ & & $(0.45)$ & & $(-1.99)$ \\
\hline \multirow[t]{2}{*}{$D \_p o s N A V$} & $-1.809^{*}$ & $-1.557^{*}$ & -0.778 & -0.753 & -0.064 & -0.243 & 0.119 & 0.128 \\
\hline & $(-1.84)$ & $(-1.68)$ & $(-1.34)$ & $(-1.51)$ & $(-0.15)$ & $(-0.65)$ & $(0.14)$ & $(0.14)$ \\
\hline \multirow[t]{2}{*}{ Constant } & 7.513 & 5.601 & -0.218 & -0.434 & $8.602 * *$ & $8.662 * *$ & 3.248 & 2.297 \\
\hline & $(1.51)$ & (1.14) & $(-0.05)$ & $(-0.10)$ & $(2.07)$ & $(2.57)$ & $(0.77)$ & $(0.60)$ \\
\hline Year FE & $\mathrm{Y}$ & $\mathrm{Y}$ & $\mathrm{Y}$ & $\mathrm{Y}$ & $\mathrm{Y}$ & $\mathrm{Y}$ & $\mathrm{Y}$ & $\mathrm{Y}$ \\
\hline Ptype FE & $\mathrm{Y}$ & $\mathrm{Y}$ & $\mathrm{Y}$ & $\mathrm{Y}$ & $\mathrm{Y}$ & $\mathrm{Y}$ & $\mathrm{Y}$ & $\mathrm{Y}$ \\
\hline Observations & 207 & 207 & 207 & 207 & 207 & 207 & 207 & 207 \\
\hline Pseudo R-squared & 0.467 & 0.455 & 0.366 & 0.360 & 0.319 & 0.280 & 0.456 & 0.429 \\
\hline
\end{tabular}

Note: Table 7 reports the probit regression result of equation (7). We test the Efficient Asset Allocation hypothesis using $D \_p o s N A V$ as the channel dummy variable. Control variables are not shown in the table but are included in every estimation. Each estimation includes year fixed effects and property-type fixed effects. Based on the corresponding t-statistic in parentheses, $* * *, * *$, and $*$ indicate statistical significance for the estimated coefficient at the $1 \%, 5 \%$, and $10 \%$ levels of confidence, respectively. Error terms are clustered by firm and robust to both heteroskedasticity and within-firm correlation. 
Table 8 Property Transaction and Credit Rating Change: Testing Efficient Asset Allocation (ROAA)

\begin{tabular}{|c|c|c|c|c|c|c|c|c|}
\hline \multirow{2}{*}{$\begin{array}{l}\text { Dependent variable: } \\
\text { Model\# }\end{array}$} & Upgrade & Upgrade & Downgrade & Downgrade & Positive & Positive & Negative & Negative \\
\hline & (1) & $(2)$ & (3) & (4) & $(5)$ & $(6)$ & (7) & (8) \\
\hline \multirow[t]{2}{*}{$A c q$} & $-3.560 * *$ & & $1.631^{*}$ & & 1.119 & & 1.128 & \\
\hline & $(-1.97)$ & & $(1.71)$ & & $(0.86)$ & & $(1.20)$ & \\
\hline \multirow[t]{2}{*}{$A c q * D \_i n c R O A A$} & 3.175 & & -2.480 & & 0.488 & & 1.762 & \\
\hline & $(1.30)$ & & $(-1.40)$ & & $(0.28)$ & & $(0.85)$ & \\
\hline \multirow[t]{2}{*}{ Disp } & -2.478 & & 0.867 & & $-8.912 *$ & & 4.370 & \\
\hline & $(-0.41)$ & & $(0.21)$ & & $(-1.90)$ & & $(1.25)$ & \\
\hline \multirow[t]{2}{*}{ Disp $* D \_i n c R O A A$} & 3.154 & & 0.024 & & 0.649 & & 2.166 & \\
\hline & $(0.64)$ & & $(0.01)$ & & $(0.16)$ & & $(0.55)$ & \\
\hline \multirow[t]{2}{*}{ Trading } & & $-3.455^{*}$ & & $1.552^{*}$ & & 0.339 & & $1.583 * *$ \\
\hline & & $(-1.83)$ & & $(1.85)$ & & $(0.24)$ & & (1.99) \\
\hline \multirow[t]{2}{*}{ Trading $* D \_i n c R O A A$} & & $3.268^{*}$ & & -1.481 & & -0.003 & & 2.201 \\
\hline & & $(1.65)$ & & $(-1.05)$ & & $(-0.00)$ & & $(1.47)$ \\
\hline \multirow[t]{2}{*}{ D_incROAA } & -0.571 & -0.557 & 0.173 & 0.182 & 0.375 & 0.281 & -0.589 & -0.593 \\
\hline & $(-1.57)$ & $(-1.47)$ & $(0.35)$ & $(0.40)$ & $(0.93)$ & $(0.67)$ & $(-1.19)$ & $(-1.25)$ \\
\hline \multirow[t]{2}{*}{ Constant } & 0.779 & 0.687 & -1.471 & -1.175 & $6.059 *$ & 4.956 & -3.668 & -3.925 \\
\hline & $(0.21)$ & $(0.18)$ & $(-0.45)$ & $(-0.34)$ & $(1.94)$ & $(1.64)$ & $(-1.08)$ & $(-1.22)$ \\
\hline Year FE & $\mathrm{Y}$ & $\mathrm{Y}$ & $\mathrm{Y}$ & $\mathrm{Y}$ & $\mathrm{Y}$ & $\mathrm{Y}$ & $\mathrm{Y}$ & Y \\
\hline Ptype FE & $\mathrm{Y}$ & $\mathrm{Y}$ & Y & Y & $\mathrm{Y}$ & $\mathrm{Y}$ & $\mathrm{Y}$ & $\mathrm{Y}$ \\
\hline Observations & 266 & 266 & 266 & 266 & 266 & 266 & 266 & 266 \\
\hline Pseudo R-squared & 0.221 & 0.220 & 0.286 & 0.284 & 0.226 & 0.175 & 0.404 & 0.395 \\
\hline
\end{tabular}

Note: Table 8 reports the probit regression result of equation (7). We test the Efficient Asset Allocation hypothesis using $D \_i n c R O A A$ as the channel dummy variable. Control variables are not shown in the table but are included in every estimation. Each estimation includes year fixed effects and property-type fixed effects. Based on the corresponding t-statistic in parentheses, $* * *, * *$, and * indicate statistical significance for the estimated coefficient at the $1 \%, 5 \%$, and $10 \%$ levels of confidence, respectively. Error terms are clustered by firm and robust to both heteroskedasticity and within-firm correlation. 
Table 9 Property Transaction and Credit Rating Change: Testing Proceeds Utilization

\begin{tabular}{|c|c|c|c|c|c|c|c|c|}
\hline Dependent variable: & Upgrade & Upgrade & Downgrade & Downgrade & Positive & Positive & Negative & Negative \\
\hline Model\# & $(1)$ & (2) & (3) & (4) & (5) & $(6)$ & (7) & $(8)$ \\
\hline$A c q$ & $\begin{array}{l}1.608 \\
(1.36)\end{array}$ & & $\begin{array}{l}0.849 \\
(0.70)\end{array}$ & & $\begin{array}{l}1.687 \\
(1.30)\end{array}$ & & $\begin{array}{c}1.822 * * \\
(2.20)\end{array}$ & \\
\hline Acq*D_decLeverage & $\begin{array}{c}6.391 * * * \\
(2.88)\end{array}$ & & $\begin{array}{l}2.154 \\
(1.22)\end{array}$ & & $\begin{array}{l}-0.545 \\
(-0.32)\end{array}$ & & $\begin{array}{l}-1.824 \\
(-0.82)\end{array}$ & \\
\hline Disp & $\begin{array}{l}-1.832 \\
(-0.55)\end{array}$ & & $\begin{array}{l}-0.238 \\
(-0.11)\end{array}$ & & $\begin{array}{l}-3.660 \\
(-0.82)\end{array}$ & & $\begin{array}{c}6.197 * * * \\
(3.26)\end{array}$ & \\
\hline Disp*D_decLeverage & $\begin{array}{l}3.139 \\
(0.91)\end{array}$ & & $\begin{array}{c}-17.009 * * * \\
(-2.63)\end{array}$ & & $\begin{array}{c}10.115^{* *} \\
(2.51)\end{array}$ & & $\begin{array}{l}-3.284 \\
(-0.96)\end{array}$ & \\
\hline Trading & & $\begin{array}{l}1.087 \\
(1.15)\end{array}$ & & $\begin{array}{l}1.039 \\
(1.23)\end{array}$ & & $\begin{array}{l}1.310 \\
(0.99)\end{array}$ & & $\begin{array}{c}2.771 * * * \\
(3.48)\end{array}$ \\
\hline Trading $* D \_d e c L e v e r a g e$ & & $\begin{array}{c}4.112 * * \\
(2.56)\end{array}$ & & $\begin{array}{l}0.480 \\
(0.29)\end{array}$ & & $\begin{array}{l}1.487 \\
(0.86)\end{array}$ & & $\begin{array}{l}-1.766 \\
(-1.17)\end{array}$ \\
\hline D_decLeverage & $\begin{array}{l}0.642 \\
(1.17)\end{array}$ & $\begin{array}{l}0.837 \\
(1.45)\end{array}$ & $\begin{array}{c}-1.361 * * \\
(-1.97)\end{array}$ & $\begin{array}{c}-1.541^{* *} \\
(-2.33)\end{array}$ & $\begin{array}{l}0.921^{*} \\
(1.95)\end{array}$ & $\begin{array}{l}0.714 \\
(1.53)\end{array}$ & $\begin{array}{l}-0.734 \\
(-0.84)\end{array}$ & $\begin{array}{l}-0.811 \\
(-0.94)\end{array}$ \\
\hline Constant & $\begin{array}{l}-0.076 \\
(-0.02)\end{array}$ & $\begin{array}{l}-0.406 \\
(-0.11)\end{array}$ & $\begin{array}{l}-0.117 \\
(-0.03)\end{array}$ & $\begin{array}{l}-0.118 \\
(-0.04)\end{array}$ & $\begin{array}{l}5.226^{*} \\
(1.76)\end{array}$ & $\begin{array}{l}4.749 \\
(1.56)\end{array}$ & $\begin{array}{l}-3.690 \\
(-1.16)\end{array}$ & $\begin{array}{l}-3.801 \\
(-1.21)\end{array}$ \\
\hline Year FE & $\mathrm{Y}$ & $\mathrm{Y}$ & $\mathrm{Y}$ & Y & $\mathrm{Y}$ & $\mathrm{Y}$ & $\mathrm{Y}$ & $\mathrm{Y}$ \\
\hline Ptype FE & $\mathrm{Y}$ & Y & Y & Y & Y & $\mathrm{Y}$ & Y & $\mathrm{Y}$ \\
\hline Observations & 266 & 266 & 266 & 266 & 266 & 266 & 266 & 266 \\
\hline Pseudo R-squared & 0.245 & 0.226 & 0.345 & 0.321 & 0.234 & 0.180 & 0.428 & 0.414 \\
\hline
\end{tabular}

Note: Table 9 reports the probit regression result of equation (7). We test the Proceeds Utilization hypothesis using $D \_d e c L e v e r a g e$ as the channel dummy variable. Control variables are not shown in the table but are included in every estimation. Each estimation includes year fixed effects and property-type fixed effects. Based on the corresponding t-statistic in parentheses, $* * *, * *$, and $*$ indicate statistical significance for the estimated coefficient at the $1 \%, 5 \%$, and $10 \%$ levels of confidence, respectively. Error terms are clustered by firm and robust to both heteroskedasticity and within-firm correlation. 
Table 10 Property Transaction and Credit Rating Change: Testing Focus

\begin{tabular}{|c|c|c|c|c|c|c|c|c|}
\hline \multirow{2}{*}{$\begin{array}{l}\text { Dependent variable: } \\
\text { Model\# }\end{array}$} & Upgrade & Upgrade & Downgrade & Downgrade & Positive & Positive & Negative & Negative \\
\hline & (1) & (2) & (3) & (4) & $(5)$ & (6) & (7) & $(8)$ \\
\hline \multirow[t]{2}{*}{$A c q$} & -0.487 & & 0.716 & & $-3.096 * *$ & & $2.986 * *$ & \\
\hline & $(-0.38)$ & & $(0.55)$ & & $(-2.42)$ & & $(2.17)$ & \\
\hline \multirow[t]{2}{*}{ Acq*D_incHHIgeo } & 0.051 & & -0.219 & & -2.160 & & -1.297 & \\
\hline & $(0.03)$ & & $(-0.11)$ & & $(-1.12)$ & & $(-0.57)$ & \\
\hline \multirow[t]{2}{*}{ Disp } & $-8.478^{*}$ & & $4.540^{*}$ & & -3.775 & & 0.472 & \\
\hline & $(-1.65)$ & & $(1.69)$ & & $(-0.58)$ & & $(0.20)$ & \\
\hline \multirow[t]{2}{*}{ Disp*D_incHHIgeo } & $-12.844 * *$ & & $7.625^{*}$ & & -5.129 & & 5.230 & \\
\hline & $(-2.37)$ & & $(1.79)$ & & $(-1.13)$ & & $(1.27)$ & \\
\hline \multirow[t]{2}{*}{ Trading } & & -0.141 & & 1.098 & & $-2.701 * *$ & & $2.763 * *$ \\
\hline & & $(-0.12)$ & & $(1.05)$ & & $(-2.21)$ & & $(2.11)$ \\
\hline \multirow[t]{2}{*}{ Trading*D_incHHIgeo } & & -0.884 & & 2.534 & & -3.495 & & 0.458 \\
\hline & & $(-0.65)$ & & $(1.40)$ & & $(-1.53)$ & & $(0.24)$ \\
\hline \multirow[t]{2}{*}{ D_incHHIgeo } & 0.179 & -0.243 & $0.849^{*}$ & 0.704 & 0.643 & 0.615 & -0.628 & -0.421 \\
\hline & $(0.37)$ & $(-0.61)$ & $(1.72)$ & $(1.47)$ & $(1.62)$ & $(1.41)$ & $(-1.45)$ & $(-1.03)$ \\
\hline \multirow[t]{2}{*}{ Constant } & -1.212 & -2.034 & -1.962 & -1.475 & $8.135 * * *$ & $8.014 * * *$ & $-10.007 * *$ & $-9.898 * *$ \\
\hline & $(-0.29)$ & $(-0.43)$ & $(-0.51)$ & $(-0.38)$ & $(2.74)$ & $(2.58)$ & $(-2.00)$ & $(-2.04)$ \\
\hline Year FE & $\mathrm{Y}$ & $\mathrm{Y}$ & $\mathrm{Y}$ & $\mathrm{Y}$ & $\mathrm{Y}$ & Y & Y & Y \\
\hline Ptype FE & $\mathrm{Y}$ & $\mathrm{Y}$ & $\mathrm{Y}$ & $\mathrm{Y}$ & $\mathrm{Y}$ & $\mathrm{Y}$ & $\mathrm{Y}$ & $\mathrm{Y}$ \\
\hline Observations & 196 & 196 & 196 & 196 & 196 & 196 & 196 & 196 \\
\hline Pseudo R-squared & 0.277 & 0.242 & 0.314 & 0.304 & 0.253 & 0.226 & 0.501 & 0.496 \\
\hline
\end{tabular}

Note: Table 10 reports the probit regression result of equation (7). We test the Focus hypothesis using $D \_i n c H H I g e o$ as the channel dummy variable. Control variables are not shown in the table but are included in every estimation. Each estimation includes year fixed effects and property-type fixed effects. Based on the corresponding t-statistic in parentheses, $* * *, *$, and $*$ indicate statistical significance for the estimated coefficient at the $1 \%$, $5 \%$, and $10 \%$ levels of confidence, respectively. Error terms are clustered by firm and robust to both heteroskedasticity and within-firm correlation. 